\title{
Investigation of the anti-inflammatory properties of hydroxypyridinones
}

\author{
S D HEWITT, ${ }^{1}$ R C HIDER ${ }^{2}$ P SARPONG, ${ }^{2}$ C J MORRIS,${ }^{3}$ AND \\ D R BLAKE
}

From the ${ }^{1}$ Cancer Research Unit, University of York, Heslington, York; the ${ }^{2}$ Department of Pharmacy, Kings College, London; and the ${ }^{3}$ Bone and Joint Unit, The London Hospital, London

SUMMARY Synovial iron deposition associated with rheumatoid disease may result in the production of highly reactive oxygen free radicals, leading to tissue damage. This chain of eventsi can be interrupted by iron chelation. Families of strong iron(III) chelators have been tested for their iron scavenging properties in vitro and their effects assessed in vivo using a rat model of inflammation. All the chelators competed successfully for iron with apotransferrin, and some removed up to $34 \%$ of iron from ferritin. The best anti-inflammatory effects were achieved with the most hydrophilic chelators and those which chelated iron most avidly. Activity was dependent on dose. The route of administration was also an important factor with lower affinity chelators.00 This work introduces a range of simple bidentate iron chelators, which under certain conditions exceed desferrioxamine in their iron scavenging abilities, and some of which, in this simpleo animal model, approach indomethacin in their anti-inflammatory capabilities.

Key words: rheumatoid arthritis, iron, iron chelators, iron overload, animal models, carrageenan pleurisy, rats, transferrin, ferritin.

Disturbance of iron metabolism is a prominent feature of rheumatoid disease ${ }^{12}$ as many patients with rheumatoid arthritis have increased concentrations of synovial fluid ferritin and iron deposits within their synovial tissue..$^{3-5}$ Iron deposition in early rheumatoid arthritis is associated with a poor prognosis ${ }^{6}$ owing to the ability of ferric iron to catalyse the production of highly reactive oxygen free radicals via a Fenton type reaction. ${ }^{78}$ Oxygen radicals such as superoxide and the hydroxyl ion are extremely reactive, having the power to damage all types of biomolecule. ${ }^{9}$ Strong iron(III) chelators will remove reactive iron and therefore limit radical production and concomitant tissue damage. ${ }^{1011}$ The reduction of iron concentrations has also been reported to influence both acute and chronic animal models of inflammation, ${ }^{12}{ }^{13}$ iron removal being achieved by chelation or nutritional iron deficiency.

Studies of the use of iron chelators in inflammation have so far been limited to desferrioxamine. This molecule is not orally active, a characteristic

Accepted for publication 12 October 1988.

Correspondence to Professor D R Blake, Bone and Joint Unit, The London Hospital, Ashfield Street, London E1 1AD. shared by many of its natural alternatives also derived from bacteria and based on hydroxamate functional groups. ${ }^{14}$ In contrast, a family of chela-o tors based on the hydroxypyridinone nucleus. (Fig. 1) has been shown to be both orally active ${ }^{15}{ }^{16}$ and capable of iron removal from hepatocytes in both iron overloaded mice ${ }^{17}$ and rabbits. ${ }^{18}$ Under? such conditions these chelators are superior to des- $\rightarrow$ ferrioxamine in their ability to remove iron. In this? paper we examine the iron scavenging properties of a series of hydroxypyridinones and hydroxypyrones and compare their effects in an animal model of inflammation.

\section{Materials and methods}

CHEMISTRY OF IRON CHELATORS

3-Hydroxypyridin-2-one and 3-hydroxypyridin-4one chelators were prepared by the methods of

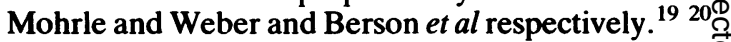
Hydroxypyrone chelators were obtained from Aldrich and recrystallised before use. The purity of these chelators was established as greater than $99 \%$ by elemental analysis. The established chelatoro 
<smiles>[R]n1cccc(O)c1=O</smiles><smiles>[R]n1ccc(=O)c(O)c1C</smiles>
HP2A $R=$ othyl
HP4A $R=$ methyl
HP2B $R=$ propyl<smiles>[R]c1cc(=O)c(O)c([R])o1</smiles><smiles>OC([Nb])O[Ga]O[Si]</smiles><smiles>O=C(Cn1ccccc1=O)N[Po](=O)[O-]</smiles>

$$
\begin{aligned}
\text { HPYA } & R_{1}=\text { methyl } \\
R_{2} & =H \\
R_{1} & =H \\
\text { HPYB } & R_{2}=\text { hydroxymethyl }
\end{aligned}
$$

desferrioxamine was obtained from Ciba Geigy. Apotransferrin (human) and ferritin (horse) were purchased from Sigma. Iron-59 was supplied by Amersham International.

The lipid solubility of both the chelators and their iron(III) complexes was assessed by determination of their partition coefficient between aqueous and organic solvents. Iron(III)-chelator complexes were prepared by the interaction of excess chelator with iron((III) chloride in trometamol (TRIS). $\mathrm{HCl}(20$

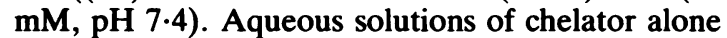
or iron-chelator complex were shaken vigorously with an equal volume of octan-1-ol in a stoppered acid washed test tube and the concentrations of chelator or iron-chelator complex in organic and aqueous layers were measured spectrophotometrically (chelator $240-400 \mathrm{~nm}$, complex $340-649 \mathrm{~nm}$ ) after centrifugation $(3000 \mathrm{rpm}$, one minute). The partition coefficient $\left(\mathrm{K}_{\text {part }}\right)$ was calculated from the ratio of concentrations in organic and aqueous layers.

The ability of the chelators to remove iron from ferritin was assessed after mixing of horse spleen ferritin $(5 \mu \mathrm{l}, 50 \%$ saturated, $180 \mu \mathrm{M})$ with chelator solution ( $3 \mathrm{mM}$ in phosphate buffered saline, $\mathrm{pH}$ 7.4). Six and 24 hours after mixing samples were passed rapidly down a Sephadex G25 column and the amount of iron removed from ferritin was determined spectrophotometrically $(350-640 \mathrm{~nm})$.
Under these conditions the column bound less than $5 \%$ of the applied iron.

Iron(III)-59 transferrin was prepared by incubation of iron-59 nitriloacetic acid (1:2) with trometamol. $\mathrm{HCl}(0.1 \mathrm{M}, \mathrm{pH} \mathrm{7.4)}$ and apotransferrin in the same buffer containing $\mathrm{NaHCO}_{3}(10 \mathrm{mM})$ for one hour at $20^{\circ} \mathrm{C} .^{21}$ Iron removal from this transferrin preparation was then assessed after exposure to excess chelator for six hours and rapid fractionation of the iron containing portion by gel permeation chromatography using Sephadex G25. Under these conditions the column bound less than $2 \%$ of the applied iron. Iron associated with the high molecular weight (transferrin) and low molecular weight (chelator) fractions was determined by gamma counting.

\section{ANIMAL STUDIES}

The non-steroidal anti-inflammatory drug indomethacin was supplied by the pharmacy, Queen Elizabeth Hospital, Birmingham. Evans blue was obtained from Gurr Microscopy Materials and carrageenan from Marine Colloids Inc.

A simple irritancy test was performed using male Wistar rats (Bantin and Kingman, Hull, UK). The animals were anaesthetised using ether, and $0.5 \mathrm{ml}$ of a $2 \%$ solution of Evans blue dye was injected intravenously. One hour later the abdomen was shaved and intradermal injections of $0.5 \mathrm{ml}$ chelator 
solutions were made. The animals were killed after one hour and the abdominal skin dissected to reveal the subcutaneous surface. Irritancy was assessed by comparing the diameter of the blue ring formed by capillary leakage with that of a buffer control.

Carrageenan pleurisy was used to assess the antiinflammatory properties of iron chelators. Male Wistar rats were housed six in a cage with food and water freely available. After an initial settlement period the animals were anaesthetised with ether and a small incision was made on the right side between third and fourth ribs, through which $0 \cdot 15$ $\mathrm{ml}$ of a $1 \%$ solution of autoclaved carrageenan was injected into the pleural space. The wound was closed with a single suture, the animals returned to their cages, and four hours later they were killed. Pleural inflammation was assessed as follows.

Samples of blood were collected by bisection of the dorsal aorta and vena cava. The pleural space was washed out with $1 \mathrm{ml}$ RPMI 1640 medium (Roswell Park Memorial Institute minimal culture medium) containing $10 \%$ chelexed fetal calf serum (Gibco). Exudate volumes were assessed by weight, smears made for differential cell counts, and samples diluted for total white cell counts (Coulter counter). After centrifugation serum and cell free exudate were stored at $-20^{\circ} \mathrm{C}$.

Groups of six animals were dosed with iron chelators one hour before and two hours after carrageenan administration. Chelators were dissolved in sterile water and the $\mathrm{pH}$ adjusted to 7 immediately before administration. A non-chelating hydroxypyridinone analogue was used as a negative control and indomethacin as the positive control. Initial screening of each chelator was by a fixed dose via the intraperitoneal route. More detailed dose response studies were then performed using the most active members of each family of iron chelators and a range of routes of administration.

\section{Results}

CHEMISTRY OF IRON CHELATORS

All three families of chelator described here combine easily with transition metals, forming neutral 3:1 complexes with trivalent cations like iron and neutral 2:1 complexes with divalent cations such as copper. ${ }^{22}{ }^{23}$ The affinity constant of the metalchelator complexes $(\log \beta)$ is a measure of their chemical attraction among other things and is derived from the logarithm of the product of the equilibrium constants relating to successive additions of atoms of metal to a single chelator molecule. Thus some of the hydroxypyridinones and hydroxypyrones have a very high affinity for iron(III) with $\log \beta_{3}>30$. Although all the chelators also possess an appreciable affinity for copper, this is markedly? exceeded by their affinity for iron. For example log $\beta_{2}$ values for the hydroxypyridin-4-ones are 27 for iron and 17 for copper, a separation of at least $1 \notin$ orders of magnitude. The hydroxypyridin-4-one chelators have a higher charge distribution than the other chelator groups considered in this study and? this renders them the most powerful group, with $\log \beta_{3}$ for iron of 37 compared with 30 for hydroxy $\overrightarrow{0}$ pyridin-2-ones and 29 for hydroxypyrones.

The chelator molecules have low proton dissociaw tion constants and are therefore uncharged a neutral $\mathrm{pH}$ and have a low affinity for $\mathrm{Ca}^{++}(\log \beta \overline{\mathrm{Q}}$ is 5 for hydroxypyridin-2-ones and hydroxypyridin ${ }_{\infty}^{+}$ 4-ones, and 4 for hydroxypyrones).

The partition coefficients for hydroxypyridin- $2 \omega_{\infty}^{\omega}$ one and hydroxypyrone metal-chelator complexe are quite high $(>1)$, which indicates a reasonable degree of lipid solubility, enabling them to cross membranes easily. Metal-chelator complexes of hydroxypyridin-4-ones, however, have partition coefficients at least one order of magnitude smallefo than the corresponding hydroxypyridin-2-ones $(0 \cdot 650$ compared with $6 \cdot 2$ for the n-propyl chelator fo example), but even this apparently low degree of hydrophobia is sufficient to facilitate membrans permeation of the iron-chelator complex.

All three families of chelator compete successfull for iron with apotransferrin. They hydroxypyridin-4 ones are the most successful at removing iron from ferritin. This might have been expected in view of their higher $\log \beta_{3}$ values (affinity) for iron(III) Under the conditions used they are more efficient than desferrioxamine.

The hydroxypyridin-4-ones will also remove iron? from ferritin without the need for simultaneous incubation with catalytic bipyridyl or ascorbic acido though the contrast between hydroxypyridin-4-ones and hydroxypyridin-2-ones in this respect is les? marked than with transferrin (Table 1). All threes families of chelator are superior to desferrioxamine. in this action.

ANIMAL STUDIES

None of the chelators possessed any appreciablew irritant properties as judged by the Evans blue capillary leakage test.

The pleurisy model was chosen for this investiga tion because it is both well established and reliable? is easily reproducible, and allows quantitative assessments to be made. Although desferrioxamine has shown anti-inflammatory properties in this model, ${ }^{24}$ its performance was exceeded in this worl by both hydroxyprones and hydroxypyridin-4-ones As initial fixed dose screening experiments showe के hydroxypyridin-2-ones to possess no appreciable 
Table 1 Iron removal from transferrin and ferritin by chelators

\begin{tabular}{|c|c|c|c|}
\hline \multirow[t]{2}{*}{ Chelator* } & \multicolumn{3}{|c|}{ Percentage removal of iron-59 from: } \\
\hline & $\begin{array}{l}\text { Transferrint } \\
\text { at } 6 \text { hours }\end{array}$ & $\begin{array}{l}\text { Ferritin } \ddagger \\
\text { at } 6 \text { hours }\end{array}$ & $\begin{array}{l}\text { Ferritin } \\
\text { at } 12 \text { hours }\end{array}$ \\
\hline $\begin{array}{l}\text { HP2A } \\
\text { HP2B }\end{array}$ & $\begin{array}{l}12 \\
15\end{array}$ & $\begin{array}{l}14 \\
11\end{array}$ & $\begin{array}{l}24 \\
21\end{array}$ \\
\hline $\begin{array}{l}\text { HP4A } \\
\text { HP4B } \\
\text { HP4C } \\
\text { HP4D }\end{array}$ & $\begin{array}{l}90 \\
88 \\
91 \\
94\end{array}$ & $\begin{array}{l}13 \\
19 \\
15 \\
17\end{array}$ & $\begin{array}{l}31 \\
34 \\
26 \\
24\end{array}$ \\
\hline HPYA & 21 & 7 & 15 \\
\hline Desferrioxamine & 17 & $1 \cdot 5$ & - \\
\hline
\end{tabular}

*Abbreviations explained in Fig 1.

† Human iron-59 transferrin $\left(10^{-5} \mathrm{M}\right)$ was incubated with a solution of chelator $\left(4 \times 10^{-3} \mathrm{M}\right)$ buffered by trometamol. $\mathrm{HCl}(0 \cdot 1 \mathrm{M}$, $\mathrm{pH} \mathrm{7.4)}$ at $25^{\circ} \mathrm{C}$ for six hours. The solution was passed down a Sephadex G25 column $(1 \times 10 \mathrm{~cm})$ and the iron- 59 associated with the high and low molecular weight fractions recorded.

¥Horse spleen ferritin (approx 50\% saturated, $180 \mu \mathrm{M}$ ) was incubated with a solution of chelator $\left(3 \times 10^{-3} \mathrm{M}\right)$ in phosphate buffered saline at $25^{\circ} \mathrm{C}$. At different times the solution was passed down a Sephadex $G 25$ column $(1 \times 10 \mathrm{~cm})$, and the amount of iron removed from ferritin was determined spectrophotometrically.

anti-inflammatory ability (Table 2) this family of chelators was excluded from further study. In contrast, both hydroxypyridin-4-ones and hydroxypyrones were found to reduce pleural inflammation significantly, the hydroxypyrones being active when given subcutaneously, whereas the hydroxypyridin4-ones were active on oral and intraperitoneal application (Table 2). The inverse relation between partition coefficients (lipid solubility) of chelators and anti-inflammatory properties is highlighted by the data shown in Table 3 . Thus the chelators having the lowest partition coefficients within their family (lowest lipid solubility) were the most efficient antiinflammatory agents. Systemic toxicity was associated with the hydroxypyridin-4-ones possessing a high partition coefficient (HP4C, HP4D). The
Table 3 Comparision of hydroxypyridin-4-ones and hydroxypyrones

\begin{tabular}{|c|c|c|c|c|c|}
\hline \multirow[t]{2}{*}{ Chelatort } & \multirow[t]{2}{*}{$K_{\text {part }} \ddagger$} & \multicolumn{2}{|c|}{ Intraperitoneal } & \multicolumn{2}{|c|}{ Subcutaneous } \\
\hline & & Exudate & Cells & Exudate & Cells \\
\hline HP4A & $0 \cdot 2$ & $50^{* *}$ & $68^{* * *}$ & $21^{* * *}$ & 74 \\
\hline HP4B & 0.4 & 97 & 97 & 85 & $86^{*}$ \\
\hline HP4C & 1.35 & 61 & 77 & - & - \\
\hline HP4D & 1.45 & 99 & 92 & - & - \\
\hline HPYA & 0.66 & $71^{*}$ & 87 & & $64^{* * *}$ \\
\hline HPYB & $0 \cdot 14$ & $75^{* *}$ & 100 & $41^{* * * *}$ & $56^{* * * *}$ \\
\hline
\end{tabular}

†Abbreviations explained in Fig. 1.

$\ddagger k_{\text {part }}=$ partition coefficient calculated from the ratio of concentrations in organic and aqueous layers.

Parameters expressed as percentages of the negative control, measured four hours after carrageenan administration. Dose $=50$ $\mathrm{mg} / \mathrm{kg}$, number of animals $=6$.

Significance assessed by Student's $t$ test: ${ }^{*} \mathrm{p}<0.05 ;{ }^{* *} \mathrm{p}<0.02$; ${ }^{* * *} p<0.01 ;{ }^{* * * *} p<0 \cdot 001$.

HP4C and HP4D were not given by the subcutaneous route owing to systemic toxicity (see text).

two most hydrophilic hydroxypyridin-4-ones were studied in greater detail by the execution of dose response experiments for each route of administration. At every dose the most hydrophilic chelator (HPA4) achieved a reduction in both exudate volume and total numbers of white cells when given subcutaneously (Fig. 2). The reduction in exudate volume was significant for doses of 2 and $50 \mathrm{mg} / \mathrm{kg}$, also exceeding the indomethacin response at these doses. In the presence of this chelator at $2 \mathrm{mg} / \mathrm{kg}$ the mean white cell count was $22.5 \times 10^{6}$ (SD $3.8 \times 10^{6}$ ), $66 \%$ of the control value of $33.4 \times 10^{6}\left(9 \cdot 8 \times 10^{6}\right)$. This compares favourably with indomethacin $(5$ $\mathrm{mg} / \mathrm{kg}$ ), which reduced the white cell count to $78 \%$ of the control level. A similar trend was obtained with HP4B, which also reduced both exudate and cell numbers.

When presented via the intraperitoneal route HP4A (5-300 mg/kg) achieved reductions in exudate volume and numbers of leucocytes (Fig. 3).

Table 2 Comparison of anti-inflammatory activity of chelator families

\begin{tabular}{|c|c|c|c|c|c|c|}
\hline \multirow[t]{2}{*}{ Chelatort } & \multicolumn{2}{|c|}{ Intraperitoneal } & \multicolumn{2}{|c|}{ Subcutaneous } & \multicolumn{2}{|l|}{ Oral } \\
\hline & Exudate & Cells & Exudate & Cells & Exudate & Cells \\
\hline $\begin{array}{l}\text { HP2A } \\
\text { HP4A } \\
\text { HPYB } \\
\text { Desferrioxamine }\end{array}$ & $\begin{array}{l}87 \\
53^{* * *} \\
75^{* *} \\
100\end{array}$ & $\begin{array}{c}83 \\
72^{*} \\
100 \\
90\end{array}$ & $\begin{array}{l}77 \\
53^{* * *} \\
41^{* * * *} \\
89\end{array}$ & $\begin{array}{l}61^{* * *} \\
94 \\
56^{* * * *} \\
88\end{array}$ & $\begin{array}{l}100 \\
67^{* * * *} \\
85 \\
-\end{array}$ & $\begin{array}{l}92 \\
79^{* *} \\
94 \\
-\end{array}$ \\
\hline
\end{tabular}

† Abbreviations explained in Fig. 1.

Parameters expressed as percentages of the negative control, measured four hours after carrageenan administration. Dose $=150 \mathrm{mg} / \mathrm{kg}$, number of animals $=6$.

Significance assessed by Student's $t$ test: ${ }^{*} p<0 \cdot 05 ;{ }^{* *} p<0 \cdot 02 ;{ }^{* * *} p<0 \cdot 01 ;{ }^{* * *} p<0 \cdot 001$. 
HPLA SUBCUTANEOUS DOSING
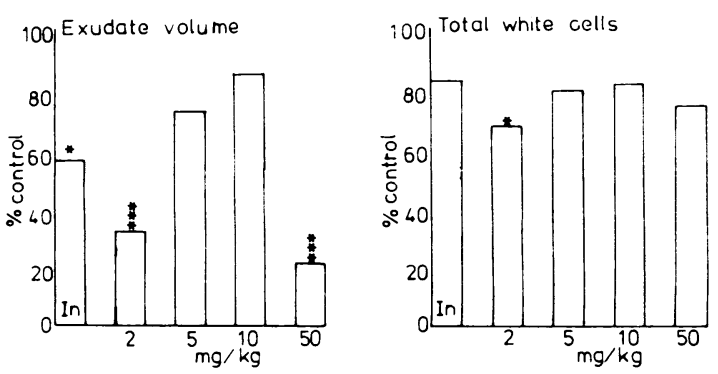

HPLB SUBCUTANEOUS DOSING
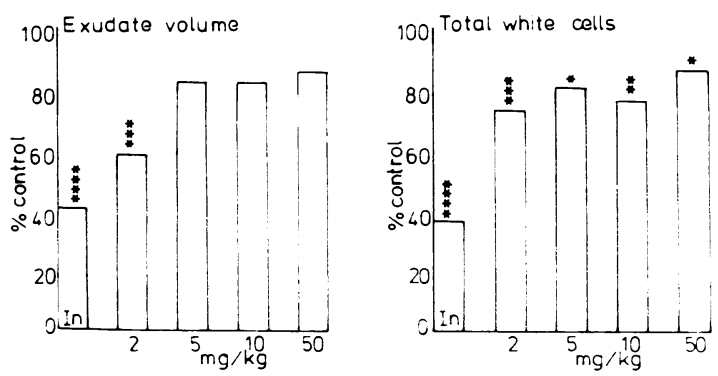

Fig. 2 Inflammatory parameters, measured four hours after carrageenan administration, expressed as percentage of the negative control. Data shown for subcutaneous dosing. Indomethacin was given orally. In=indomethacin. For other abbreviations see Fig. 1. Significance was calculated by Student's t test: ${ }^{*} p<0.05 ;{ }^{* *} p<0.02 ;{ }^{* * *} p<0.01$; ${ }^{* * * *} p<0 \cdot 001$.

The reduction in the number of cells accumulating in the pleural cavity was significant at each dose tested. In contrast, HP4B was less effective than when given subcutaneously, achieving significant reductions in inflammatory parameters only at high doses $(>100 \mathrm{mg} / \mathrm{kg})$.

On oral presentation HP4A diminished both numbers of white cells and volumes of exudate at all doses (Fig. 4). When given in excess of $50 \mathrm{mg} / \mathrm{kg}$ this chelator triggered increased salivation in animals within 30 minutes of application. In parallel with its effects after intraperitoneal administration, HP4B failed to influence the inflammatory process when given orally even at high doses such as 150 and 300 $\mathrm{mg} / \mathrm{kg}$.

Thus HP4A possesses anti-inflammatory properties when presented by three different routes, whereas HP4B is only active when given subcutaneously.

\section{Discussion}

When undergoing a respiratory burst, eosinophils,
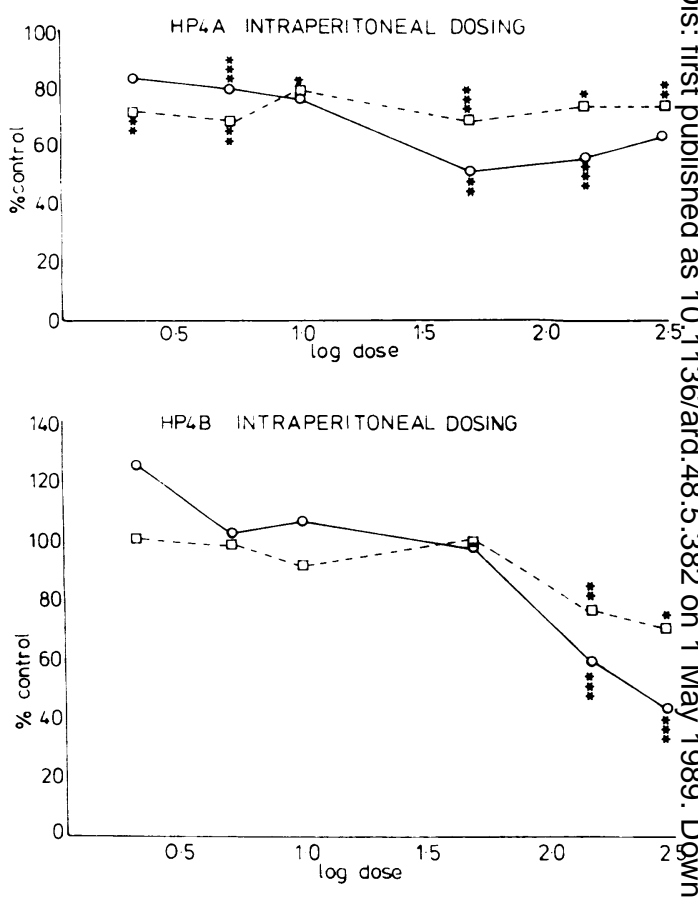

Fig. 3 Inflammatory parameters, measured four hours after carrageenan administration, expressed as percentage of the negative control. Data shown for intraperitoneal dosing $\square-.-\square=$ white cell count $; \bigcirc-O=$ exudate volume. Signio ficance was assessed by Student's t test ${ }^{*} p<0 \cdot 05 ;{ }^{* *} p<0 \cdot 02$ ? ${ }^{* * *} p<0 \cdot 01$.

monocytes, macrophages, and neutrophils produce् superoxide free radicals and hydrogen peroxide. ${ }^{25} \mathrm{H}$ is thought that these species have an important rote in the phagocyte mediated tissue injury associated with inflammation, ${ }^{12}$ although when homogeneous they are poorly reactive in aqueous solution and therefore unlikely to be directly responsible for an observed tissue damage. ${ }^{26}$ In the presence of suino able transition metal catalysts such as copper or iron, however, superoxide and hydrogen peroxide react to produce the hydroxyl radical, a highlos reactive tissue damaging species. ${ }^{27}$ Iron in a for able to catalyse this reaction has been demonstrated in human synovial fluid. ${ }^{28}$

An improvement in both acute and chron inflammation was noted on administration of desfer만 rioxamine to animal models. ${ }^{29}$ When given to rheumatoid patients, however, desferrioxamine caused reversible ocular abnormalities, and c\& administration with phenathiazines led to loss of consciousness for up to 72 hours. ${ }^{30}$ In contrast lower doses of desferrioxamine administered 
HPLA ORAL DOSING
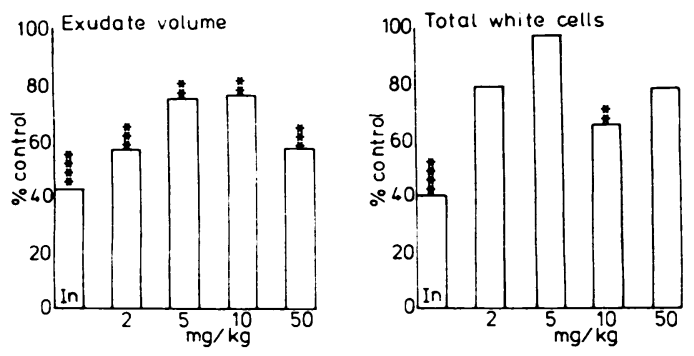

HPLB ORAL DOSING
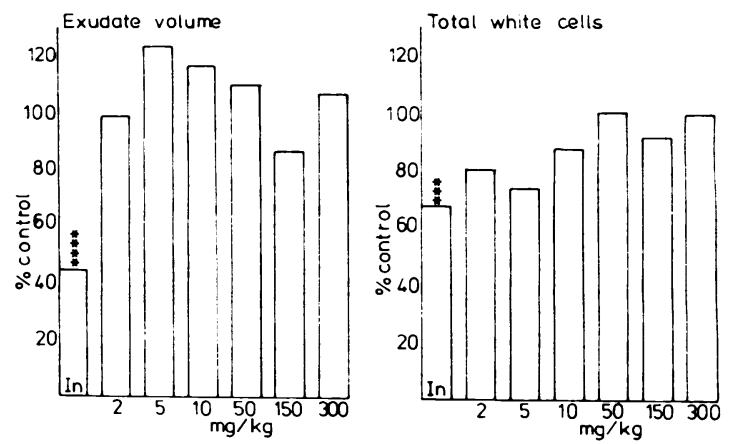

Fig. 4 Inflammatory parameters, measured four hours after carrageenan administration, expressed as percentage of the negative control. Data shown for intraperitoneal dosing. Indomethacin was also given orally. In=indomethacin. For other abbreviations see Fig. 1. Significance was calculated by Student's t test ${ }^{*} p<0.05 ;{ }^{* *} p<0.02 ;{ }^{* * *} p<0.01$ ${ }^{* * * *} p<0.001$.

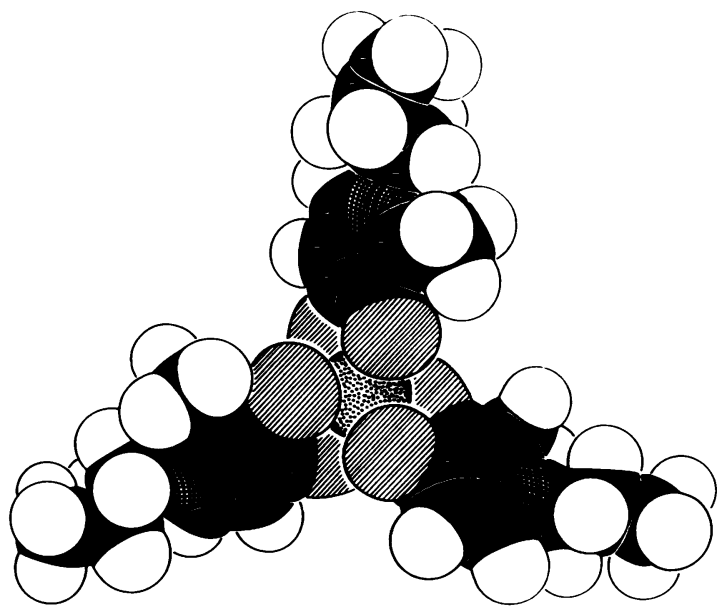

Fig. 5 Spatial arrangement of iron(III)-chelator complex. anaemic rheumatoid patients had the effect of suppressing both inflammation and anaemia. ${ }^{31}$

The need to overcome the shortcomings of desferrioxamine (parenteral administration and lack of specificity for iron) led to the development of the chelators which have been examined in this study. Hydroxypyridin-4-ones have been shown to be capable of mobilising iron from transferrin and ferritin in vitro ${ }^{32}$ and from iron overloaded animals in vivo, for example, mice ${ }^{15-17}$ and rabbits. ${ }^{18}$

With suitable alkyl substituents these chelators and their iron complexes can be rendered both water soluble and membrane permeable. They are remarkably resistant to acid conditions, to oxidation, and to the action of proteolytic enzymes. All these properties favour both survival in and absorption from the gastrointestinal tract.

In this study the most hydrophilic member of the hydroxypyridin-4-ones family (HP4A) has been shown to possess anti-inflammatory activity in the acute carrageenan pleurisy model, regardless of the route of administration. Although the others in this family of chelators also demonstrated activity in this model (data not shown), these more lipid soluble members of the family induced much smaller changes in the various parameters of inflammation. Only HP4B was found to have equivalent activity to HP4A and then only when presented subcutaneously.

The closely related hydroxypyridin-2-ones were much less effective than the hydroxypyridin-4-ones, possibly owing to their lower affinity for iron(III) or higher partition coefficient values for both chelators and iron(III)-chelator complexes, or both. The hydroxypyrones were found to be quite active when given subcutaneously (Table 3), however when given by the intraperitoneal route they possessed anti-exudative properties only. They had no beneficial effects after oral administration, presumably because of rapid metabolism. ${ }^{33}$

Using a simple model of acute inflammation we have demonstrated the efficacy of iron chelation in reducing inflammation. In our tests the most effective of the bidentate chelators described here were the hydroxypyridin-4-ones. Of these, the best was the simplest, most water soluble chelator HP4A. This chelator is markedly more effective than desferrioxamine in the tests described in this work. Indeed even some of the less attractive chelatorsfor example, HP4B, HPYA, and HPYB, are more active than this well characterised high affinity iron(III) chelator.

The bidentate hydroxypyridin-4-ones form stable 3:1 complexes with iron (Fig. 5), which completely protect the iron(III) atom from the surrounding solvent. Consequently, once formed, the iron(III)chelator complex has an extremely low tendency to 
produce hydroxyl radicals ${ }^{34}$ and therefore scavenge iron in a non-toxic form. Although the bidentate hydroxypyridin-4-ones possess a high affinity for iron(III), the neutral complexes dissociate at low concentrations to form the charged $2: 1$ complex. ${ }^{22}$ It is conceivable that such dissociation limits the effectiveness of these molecules. Dissociation at low concentrations is much less likely with hexadentate chelators, which form 1:1 complexes with iron(III). ${ }^{14}$ We are currently studying a range of such chelators.

We are grateful to the British Technology Group and the Arthritis and Rheumatism Council for their financial support. Technical assistance was provided by Ann Bowler and Julie Hopkins.

\section{References}

1 Lawson A A H, Owen E T, Mowat A G. Nature of anaemia in rheumatoid disease. VII. Storage of iron in rheumatoid disease. Ann Rheum Dis 1967; 26: 552-9.

2 Harvey A R, Clarke B J, Chui D H K, Kean W F, Buchanan $M$ W. Anaemia associated with rheumatoid disease. Inverse correlation between erythropoiesis and both IgM and rheumatoid factor levels. Arthritis Rheum 1983; 26: 28-34.

3 Muirden K D. Ferritin in synovial cells in patients with rheumatoid arthritis. Ann Rheum Dis 1966; 25: 387-401.

4 Senator G B, Muirden K D. Concentration of iron in synovial membrane, synovial fluid and serum in rheumatoid arthritis and other joint diseases. Ann Rheum Dis 1968; 27: 49-53.

5 Blake D R, Bacon P A. Synovial fluid ferritin in rheumatoid arthritis: an index or cause of inflammation. Br Med J 1981; 282: 189.

6 Blake D R, Gallagher P J, Potter A R, Bell M J, Bacon P A. The effect of synovial iron on the progression of rheumatoid disease. A histological assessment of patients with early rheumatoid disease. Arthritis Rheum 1984; 27: 495-501.

7 Halliwell B. Superoxide dependent formation of hydroxyl radicals in the presence of iron salts. Its role in degradation of hyaluronic acid by a superoxide generating system. FEBS Lett 1978; 96: 238-44.

8 Aust S D, Morehouse L A, Thomas C E. Hypothesis paper: Role of metals in oxygen radical reactions. Journal of Free Radicals in Biology and Medicine 1985; 1: 3-25.

9 Henriksen T, Melo T B, Saxebol G. Free radical formation in proteins and protection from radiation damage. In: Pryor W A, ed. Free radicals in biology. Vol 2. New York: Academic Press, 1976: 213-56.

10 Halliwell B. Use of desferrioxamine as a probe for iron dependent formation of hydroxyl radicals. Evidence for a direct reaction between desferal and the superoxide radical. Biochem Pharmacol 1985; 34: 229-33.

11 Starke P E, Farber J L. Ferric iron and superoxide ions are required for the killing of cultured hepatocytes by hydrogen peroxide. Evidence for the participation of hydroxyl radicals formed by a Haber Weiss reaction. J Biol Chem 1985; 260: 10099-104

12 Blake D R, Hall N D, Bacon P A, Dieppe P A, Halliwell B, Gutteridge J M C. Effect of a specific iron chelating agent on animal models of inflammation. Ann Rheum Dis 1983; 42: 89-93.

13 Andrews F, Morris C J, Kondratowicz G, Blake D R. The effect of iron chelation on inflammatory joint disease. Ann Rheum Dis 1987; 46: 327-33.

14 Hider R C. Siderophore mediated absorption of iron. Structures and Bonding 1984; 58: 25-87.

15 Hider R C, Kontoghiorghes G, Silver J, Stockham M A. Pharmaceutical compositions. UK patent 1983: GB2118176A. $\overline{\bar{C}}$.

16 Gyparaki M, Hider R C, Huehns E R, Porter J B. Hydroxypyr-idone iron chelators: in vitro and in vivo evaluation. In: Sirchia G, Zanella A, eds. Thalassaemia today. Milan: Polialinico deg Milano Editare, 1985: 521-6.

17 Gyparaki M, Porter J B, Hirani S, Streater M, Hider R C $\overrightarrow{0}$ Huehns E R. In vivo evaluation of hydroxypyridone ironchelators in a mouse model. Acta Haematol (Basel) 1987; 78 $\vec{\omega}$ 217-21.

18 Kontoghiorghes G, Hoffbrand A V. Orally active ketohydroxy pyridine iron chelators intended for clinical use: studies in rabbits. Br J Haematol 1986; 62: 607-13.

19 Mohrle H, Weber H. Zur Kenntuis der 1-methyl-3-hydroxy pyridone-(2) und -(6). Tetrahedron 1970; 26: 3779-85

20 Berson J A, Jones W M, O'Callaghan L F. Spectra as a guide to structure in the hydroxypyrone and hydroxypyridone series? Journal of the American Chemical Society 1956; 78: 622-3.

21 Bates G W, Wernicke J. The kinetics and mechanism of iron(III) exchange between chelates and transferrin. IV. The reaction of transferrin with iron(III) nitriloacetate. J Biol Chem 1971; 246: 3679-85.

22 Taylor P D, Morrison I E G, Hider R C. Application of nork linear regression analysis to metal ligand equilibrium. Talanta 1988; 35: 507-12.

23 Scarrow R C, Riley P E, Abu-Dari K, White D L, Raymondo K N. Ferric ion sequestering agents. Inorganic Chemistry $1985 ;$ 24: 954-67.

24 Sedgwick A D, Blake D R, Winwood P, Moore A R, Al-Duaijo A. Willoughby D A. Studies into the effects of the iron chelatoro desferrioxamine on the inflammatory process. Eur J Rheumato Inflamm 1984; 7: 87-94.

25 Babior B M. Oxygen dependent microbial killing by phago-o cytes. $N$ Engl J Med 1978; 298: 721-5.

26 Halliwell B, Gutteridge J M C. Oxygen toxicity, oxygen radicals, transition metals and disease. Biochem $J$ 1984; 219:0 $1-14$

27 Ward P A, Till G O, Kunkel R, Beauchamp C. Evidence for the role of hydroxyl radical in complement and neutrophifmediated tissue injury. $J$ Clin Invest 1983; 72: 789-801.

28 Gutteridge J M C, Halliwell B, Rowley D A. Catalytic iron complexes in biological material: a potential for oxygen radicab damage. Life Chemistry Reports. 1984; 2 (suppl): 15-26.

29 Yoshino S, Blake D R, Bacon P A. The effect of desferriox-o amine on antigen induced inflammation in the rat air pouch. $J$ Pharm Pharmacol 1984; 36: 543-5.

30 Blake D R, Winyard P, Lunec J, et al. Cerebral and ocula음 toxicity induced by desferrioxamine. $Q J$ Med 1985; 219 345-55.

31 Giordano N, Sancasciani A, Borghi C, Fioravanti A, Marcolongo $\mathbf{R}$. Anti anaemic and potential anti inflammatory activity of desferrioxamine: possible usefulness in rheumatoid arthritis. Clin Exp Rheumatol 1986; 4: 25-9.

32 Brady M C, Lilley K S, Treffry A, Harrison P M, Hider R C. Release of iron from ferritin molecules and their iron-cores bye 3-hydroxypyridine chelators in vitro. $J$ Inorg Biochem (in press).

33 Rennhard $\mathrm{H} \mathrm{H}$. The metabolism of ethyl maltol and maltol int the dog. Journal of Agriculture and Food Chemistry 1971; 190 $152-4$.

34 Singh S, Hider R C. Colorimetric determination of the hydroxyP radical: comparison of the hydroxyl radical generating ability o $\mathbb{Z}$ various iron complexes. Anal Biochem 1988; 171: 47-54. . 